\title{
Microscopic Leaf Constant Numbers of Chromolaena odorata in Thailand
}

\author{
Yamon Pitakpawasutthi ${ }^{1}$, Chanida Palanuvej ${ }^{1}$, Nijsiri Ruangrungsi ${ }^{1,2, *}$
}

\section{Yamon Pitakpawasutthi', Chanida Palanuvej', Nijsiri Ruangrungsi ${ }^{1,2, *}$}

\author{
'Public Health Sciences Program, \\ College of Public Health Sciences, \\ Chulalongkorn University, Bangkok \\ 10330, THAILAND. \\ ${ }^{2}$ Department of Pharmacognosy \\ and Pharmaceutical Botany, \\ Faculty of Pharmacy, Rangsit University, \\ Pathumthani 12000, THAILAND. \\ Correspondence \\ Dr. Nijsiri Ruangrungsi \\ College of Public Health Sciences, \\ Chulalongkorn University, Bangkok 10330 \\ THAILAND \\ Phone no : +662-218-8158 \\ E-mail: nijsiri.r@chula.ac.th \\ History \\ - Submission Date: 19-04-2018; \\ - Review completed: 28-06-2018; \\ - Accepted Date: 09-08-2018 \\ DOI : $10.5530 /$ pj.2018.6s.18
}

Article Available online

http://www.phcogj.com/v10/i6s

\section{Copyright}

(C) 2018 Phcog.Net. This is an openaccess article distributed under the terms of the Creative Commons Attribution 4.0 International license.

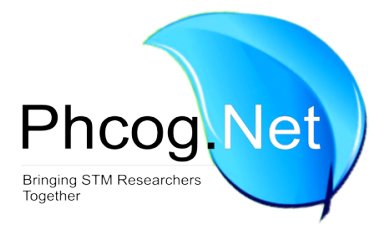

\begin{abstract}
Introduction: Chromolaena odorata (L.) R.M. King and H. Rob. (syn. Eupatorium odoratum L.), commonly known as Siam Weed, Christmas Bush, or Common Floss Flower, is a species in family Asteraceae. It has been widely used as medicinal plants for a long time. In Thailand, C. odorata is locally used to treat skin diseases and insect bites. Leave juice from the crushed leaves can be used as a haemostatic and anti-inflammatory in the treatment of skin wounds. Objective: This study aimed to investigate the leaf constant values of microscopic characters of leaf in term of stomatal number, stomatal index, epidermal cell number, trichome number, trichome index and oil gland number of $C$. odorata in Thailand. Method: Microscopic evaluation of leaf constants are frequency used for the medicinal plant samples. Leaf constant numbers used to identify between some closely related species. Light microscope (LM) attached a digital camera and scanning electron microscope (SEM) were used in this study. Results and Conclusion: The results showed anomocytic stomata and multicellular non-glandular trichomes on both upper and lower epidermis of $C$. odorata, while oil glands were found on only lower epidermis of the leaf. The microscopic leaf constant numbers of $C$. odorata were established and could be used for the species identification of $C$. odorata in Thailand.

Key words: Chromolaena odorata, Stomata number, Trichome number, Oil gland number, Epidermal cell number.
\end{abstract}

\section{INTRODUCTION}

Chromolaena odorata (L.) R.M. King and H. Rob. (syn. Eupatorium odoratum L.), commonly known as Siam Weed, Christmas Bush, or Common Floss Flower, is a species in family Asteraceae. C. odorata is a fast-growing perennial shrub distributed in Asia, Africa and the Pacific. It may reach 1 meter or more as a free standing shrub. The leaves are opposite, deltoid to ovate-lanceolate with three-nerved leaves and aromatic when crushed. It has a long-pointed tip and dentate margin. The inflorescences are corymbs with cylindrical heads located on the terminals of lateral branches. It presents in blue, pink, lavender, or white color. The seeds are a brownish gray to black achene with a pale brown pappus. It is sometimes grown as an ornamental and medicinal plant. ${ }^{1}$ In Thailand, C. odorata is locally used to treat skin diseases and insect bites. Leave juice from the crushed leaves can be used as a haemostatic and anti-inflammatory in the treatment of skin wounds. ${ }^{2}$ In terms of medicinal uses, leaf extracts is used in the treatment of colds and sometimes sore throats or cough when used with salt. ${ }^{3}$ Extracts of $C$. odorata have been shown to inhibit Neisseria gonorrhoeae that causes gonorrhoea in vitro and to accelerate blood clotting. ${ }^{4-5}$ The pharmacological activities of $C$. odorata have been shown a wide biological activities such as anthelmintic activity, insecticidal activity, analgesic activity, anti-inflamma- tory, antimicrobial, blood coagulating, insecticidal and antioxidant activities and many other medicinal properties. ${ }^{1,6}$

The microscopic examination is one of the quality control process for herbal material to determine the characteristics, identity and degree of purity of medicinal plant materials, and should be carried out before any further tests are undertaken. ${ }^{7}$ Microscopic leaf constant numbers are frequently used to identify between some closely related species. It has great value for a quality of the medicinal plants based on these specific characters. ${ }^{8}$ The leaf constant numbers of $C$. odorata in Thailand has never been established. Therefore, the present study aimed to investigate the leaf constant values of microscopic characters of leaf in term of stomatal number, stomatal index, epidermal cell number, trichome number, trichome index and oil gland number of C. odorata in Thailand. Light microscope (LM) attached a digital camera and scanning electron microscope (SEM) were used in this study.

\section{MATERIALS AND METHODS}

\section{Plant materials}

The fresh mature leaves of $C$. odorata were collected from different locations throughout Thailand. Plant 
samples were authenticated by one of the authors, Ruangrungsi N. The voucher specimens were deposited at College of Public Health Sciences, Chulalongkorn University for future references.

\section{Leaves preparation}

Fresh mature leaves were cleaned. The leaf portion between midrib and margin from the middle region was cut into small pieces $\left(10 \times 10 \mathrm{~mm}^{2}\right)$. Tissues were disintegrated by poaching leaf samples in $10 \%$ hydrochloric acid under low heat for $1 \mathrm{hr}$. They were immersed in Haiter ${ }^{\mathrm{TM}}$ bleach solution containing $6 \%$ sodium hypochlorite (50\% in water) until chlorophyll was removed. When bleaching was completed, leaf samples were washed with water and then cleared by gently warming with chloral hydrate solution ( $4 \mathrm{~g}$ of chloral hydrate $/ 1 \mathrm{ml}$ of water) until it was transparent. After rinsing with water, the leaf sample was mounted with glycerin and observed under a light microscope (Zeiss Axio Imager A2) with an attached digital camera (Cannon Power shot A640) for the determination of leaf constants.

\section{Microscopic analysis}

Microscopic evaluation of leaf constants such as stomatal number, stomatal index, epidermal cell number, trichome number, trichome index and oil gland number were examined. Thirty fields of plant sample were carried out and determined using Axio Vision program.

\section{Determination of stomatal number and stomatal index}

Stomatal number is an average number of stomata per square millimeter $\left(\mathrm{mm}^{2}\right)$ of epidermis of the leaf. Stomatal index (SI) is a percentage of stomata from the total number of epidermal cells in a same unit area of leaf, ${ }^{9}$ which can be calculated as:

$$
\mathrm{SI}=\frac{\mathrm{S}}{\mathrm{S}+\mathrm{E}+\mathrm{T}} \times 100
$$

Where, $S=$ number of stomata per $\mathrm{mm}^{2}$ in a given area of leaf

$\mathrm{E}=$ number of epidermal cells per $\mathrm{mm}^{2}$ in the same area of leaf

$\mathrm{T}=$ number of trichomes per $\mathrm{mm}^{2}$ in the same area of leaf

\section{Determination of epidermal cell number}

Epidermal cell number is an average number of epidermal cell per $\mathrm{mm}^{2}$ of leaf surface. The number of epidermal cell on the upper and lower surface of leaf in $1 \mathrm{~mm}^{2}$ in each field were counted.

\section{Determination of trichome number and trichome index}

Trichome number is an average number of trichome per $\mathrm{mm}^{2}$ of epidermis of leaf surface. The number of trichome on the upper and lower surface of leaf in $1 \mathrm{~mm}^{2}$ in each field were counted. Trichome index (TI) is a percentage of trichome from the total number of epidermal cells in a same unit area of leaf, which can be calculated as:

$$
\mathrm{TI}=\frac{\mathrm{T}}{\mathrm{S}+\mathrm{E}+\mathrm{T}} \times 100
$$

Where, $S=$ number of stomata per $\mathrm{mm}^{2}$ in a given area of leaf

$\mathrm{E}=$ number of epidermal cells per $\mathrm{mm}^{2}$ in the same area of leaf

$\mathrm{T}=$ number of trichomes per $\mathrm{mm}^{2}$ in the same area of leaf

\section{Determination of oil gland number}

Oil gland number is an average number of oil gland per $\mathrm{mm}^{2}$ of leaf surface. The number of oil gland on the lower surface of leaf in $1 \mathrm{~mm}^{2}$ in each field were counted.

\section{Scanning electron microscope (SEM) evaluation}

The leaf samples were examined by scanning electron microscope (JEOL, model JSM-5410LV, Japan). The leaf was cut about $5 \mathrm{~mm}^{2}$ and mounted on the stub with double sided adhesive tabs. After that, the specimens were coated with gold in sputter coater, then examined with scanning electron microscope at $15 \mathrm{kV} .^{10}$

\section{Data analysis}

All leaf constant parameters were determined at least in thirty fields of plant sample. The results expressed as mean \pm standard deviation (SD), minimum and maximum values.

\section{RESULTS AND DISCUSSION}

Microscopic leaf constant values are possibly used to distinguish between some closely related species of which cannot clearly characterized by general microscopy. ${ }^{9}$ Microscopic evaluation should be the first step to identify the plants. ${ }^{11}$ The results of leaf constant numbers consisting of stomatal number, stomatal index, epidermal cell number, trichome number, trichome index and oil gland number were shown in Table 1. In this study, the epidermal cell numbers of $C$. odorata on lower epidermis surface could not be counted to calculate the constant values of the stomatal and trichome indices because all of the oil gland cells in this species shielded some epidermal cells around these oil glands.

The stomatal number and stomatal index are very specific criteria for identification and characterization of herbal crude drug. ${ }^{12}$ Although the stomatal number varies greatly with the age of the leaf, the stomatal index remains highly consistent. The one of microscopic evaluation which can distinguish plant species is stomatal type by their form and arrangement in the surrounding cells. The different types of stoma are often available for matured leaves that are distinguished by their form and arrangement in the surrounding cells. In recent study, the stomata type of $C$. odorata was classified as anomocytic or ranunculacious type of stomata (Figure 1). The stomata is surrounded by varying number of cells, which are generally not different from those of the epidermis which supported in characteristics of $C$. odorata. ${ }^{7}$ The stomata were found on both upper epidermis and lower epidermis which called amphistomatic leaf as distribution of stomata. The previous studies also reported that the stomata type of $C$. odorata were anomocytic type. ${ }^{13-15}$

Trichomes are epidermal protuberances located on aerial parts of plant, that protect plant from excess transpiration, high temperature, ultraviolet light, and herbivore attack. Trichome number has been used for identification of some plants that have trichomes covering their leaves. ${ }^{16}$ The results showed that there were multicellular uniseriate trichomes

\section{Table 1: Microscopic leaf constant numbers of Chromolaena odorata in} Thailand.

\begin{tabular}{lcccc}
\hline \multirow{2}{*}{$\begin{array}{c}\text { Leaf constant } \\
\text { values }\end{array}$} & \multicolumn{2}{c}{ Upper epidermis } & \multicolumn{2}{c}{ Lower epidermis } \\
\cline { 2 - 5 } & min-max & mean \pm SD & min-max & mean \pm SD \\
\hline Stomatal number & $72-108$ & $87.07 \pm 9.95$ & $240-408$ & $348.53 \pm$ \\
& & & & 44.67 \\
Stomatal index & $5.40-8.22$ & $6.43 \pm 0.65$ & nd & nd \\
$\begin{array}{c}\text { Epidermal cell } \\
\text { number }\end{array}$ & $1084-1424$ & $1263.33 \pm 89.28$ & nd & nd \\
$\begin{array}{c}\text { Trichome number } \\
\text { Trichome index }\end{array}$ & $0.003-0.006$ & $0.004 \pm 0.001$ & nd & nd \\
Oil gland number & Absent & Absent & $8-16$ & $12.40 \pm 3.04$ \\
\hline
\end{tabular}

*nd: not detected. 


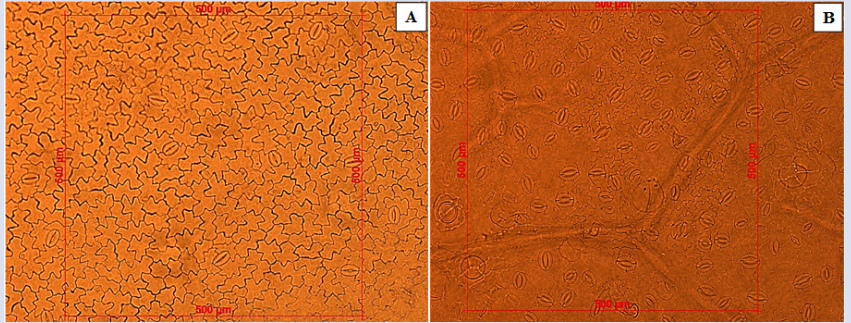

Figure 1: Light microscope photographs of stomata on the (A) upper and (B) lower epidermis of Chromolaena odorata.

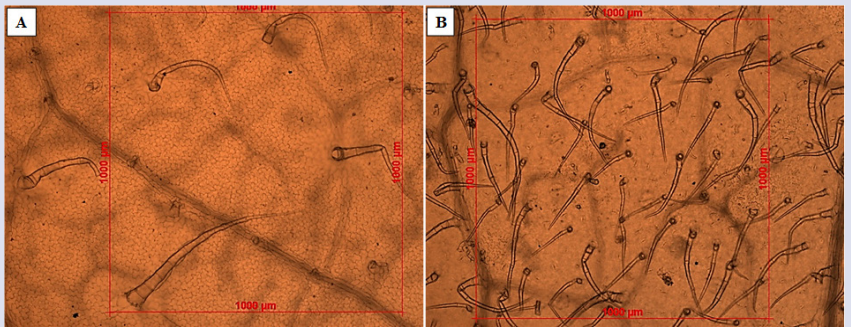

Figure 2: Light microscope photographs of trichome on the (A) upper and (B) lower epidermis of Chromolaena odorata.

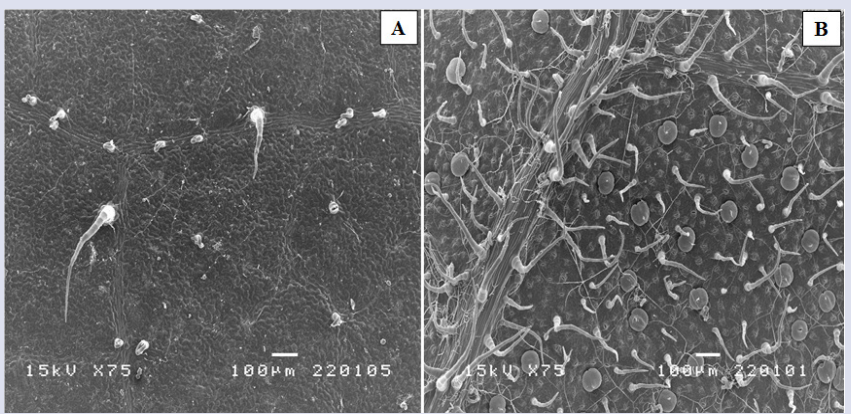

Figure 3: Scanning electron micrographs of Chromolaena odorata trichomes on both (A) upper and (B) lower epidermis.

on both upper and lower epidermis of $C$. odorata (Figure 2, 3). Micrographs of the trichome characteristic were taken from scanning electron microscope were demonstrated in Figure 4. The trichome number on the upper epidermis was found to be $5.17 \pm 1.12$, which was less than that of the lower epidermis $(47.40 \pm 3.04)$. The result of this study is in accordance with the previous researches reported that $C$. odorata leaf had many long multicellular uniserate unbranched trichomes. ${ }^{13-14}$

Essential oils are complex, volatile mixtures of certain secondary plant metabolites. A wide range of plant species produce essential oils. In addition, essential oils are most commonly found in special secretory structures either on the surface of the plant or within the plant tissues. The type of structure is specific to the family or species. This can be useful to identify plant material and verify the authenticity of the plant source in the case of suspected adulteration. The secretory tissues can be examined

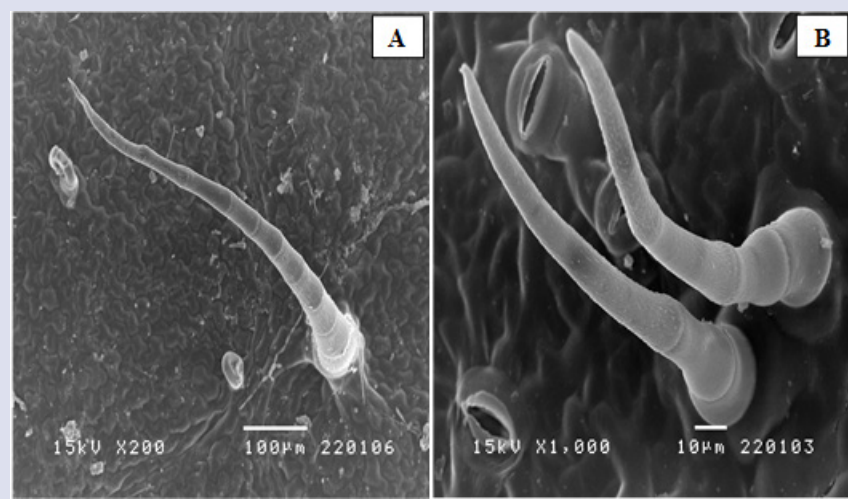

Figure 4: Scanning electron micrographs of the trichome characteristic on both (A) upper and (B) lower epidermis of Chromolaena odorata (multicellular uniseriate trichome type).

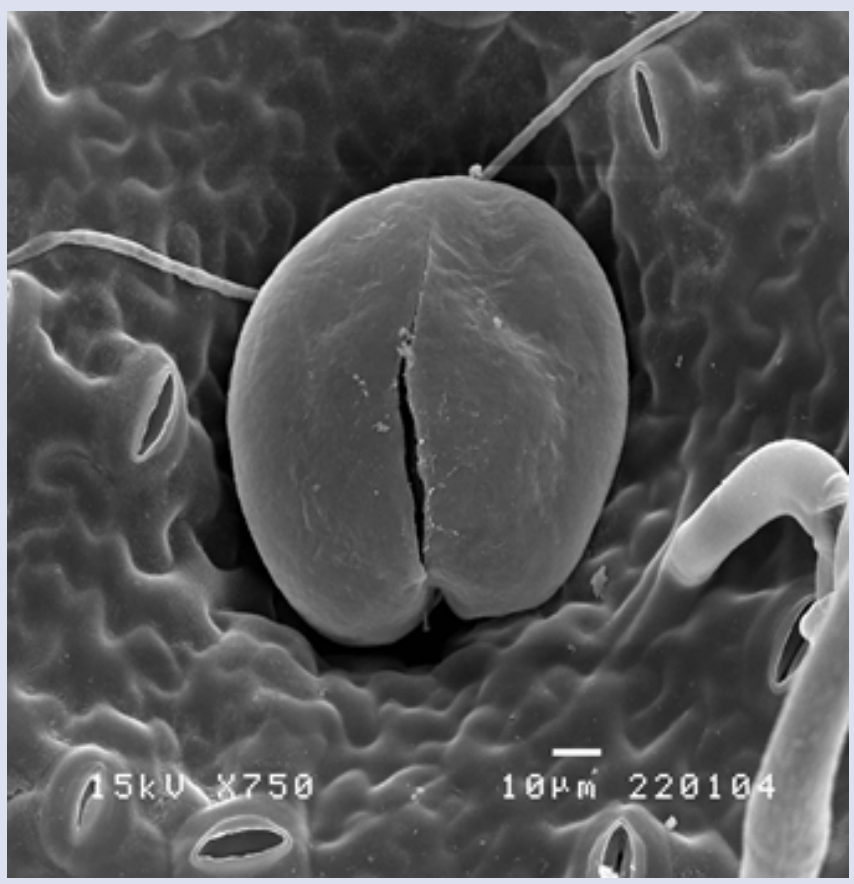

Figure 5: Scanning electron micrograph of oil gland from Chromolaena odorata leaf.

using scanning electron microscopy, which enables detailed observation of major stages in the secretory cells including their membrane system and the overall size of the gland. ${ }^{17}$ In this study, the glandular trichomes were found on only lower epidermis of C. odorata (Figure 3B). The scanning electron micrograph of glandular trichome from $C$. odorata leaf was demonstrated in Figure 5. The circular structure is embedded in the shallow pits of epidermis is an oil gland, a modified glandular hair which secretes oils to give the plant its aroma. C. odorata has such oil glands lying in the epidermis of the leaf. This also explains that the leaves are aromatic when crushed. The previous study also reported that there were glandular trichome located in shallow pits, mostly on the abaxial side. The gland is sessile, broadly bowl shaped and consist of two vertical rows of cells. ${ }^{13}$ Moreover, the powder microscopy of C. odorata leaf revealed presence glandular trichomes. ${ }^{18}$ 


\section{CONCLUSION}

The established microscopic leaf constant numbers such as stomatal number, stomatal index, epidermal cell number, trichome number, trichome index and oil gland number could be used as an important tool for identification parameters of $C$. odorata in Thailand.

\section{ACKNOWLEDGEMENT}

The authors wish to thank College of Public Health Sciences, Chulalongkorn University and all staff members for necessary assistance and instrument supports.

\section{CONFLICT OF INTEREST}

The authors declare no conflicts of interest.

\section{ABBREVIATIONS}

LM: Light microscope; SEM: Scanning electron microscope; $\mathbf{m m}^{\mathbf{2}}$ : square millimeter; SI: Stomatal index; TI: Trichome index; SD: Standard deviation; nd: not detected.

\section{REFERENCES}

1. Chakraborty AK, Rambhade S, Patil UK. Chromolaena odorata (L.): An Overview. J Pharm Res. 2011;4(3):573-6.

2. Sirinthipaporn A, Jiraungkoorskul W. Wound Healing Property Review of Siam Weed, Chromolaena odorata. Pharmacogn Rev. 2017;11(21):35-8.

3. Suksamrarn A, Chotipong A, SuavansriT, Boongird S, Timsuksai P, Vimuttipong S, et al. Antimycobacterial Activity and Cytotoxicity of Flavonoids from the Flowers of Chromolaena odorata. Arch Pharm Res. 2004;27(5):507-11.

4. Chuaynugul A, Caceres A, Menendez H, Mendez E. Antigonorrheal activity of plants used in Guatemala for the treatment of sexually transmitted diseases.
J Ethnopharmacol. 1995;48(2):85-8.

5. Triratana T, Suwannuraks R, Naengchomnong W. Effect of Eupatorium odoratum on blood coagulation. J Med Assoc Thai. 1991;74(5):283-7.

6. Mishra D, Sarkar DK, Nayak BS, Rout PK, Ellaiah P, Ramakrishna S. Phytochemical investigation and evaluation of anthelmintic activity of extract from leaves of Eupatorium odoratum linn. Indian J Pharm Educ Res. 2010;44(4):369-74.

7. World Health Organization. Quality control methods for medicinal plant materials Geneva: WHO Press. 2011.

8. Eames AJ, Mac Daniels LH. An introduction to Plant Anatomy. New York: McGraw-Hill. 1974.

9. Evans WC. Trease and evans pharmacognosy. $16^{\text {th }}$ ed. Edinburgh: Saunders/ Elsevier. 2009.

10. Patil VS, Malpathak NP. Micro-morphoanatomical approach for comparative analysis of Tinospora cordifolia (Willd.) Miers and its adulterant plant using SEM and Cryostat. Pharmacogn J. 2017;9(1):39-45

11. Thitikornpong W, Ongpipattanakul B, Palanuvej C, Ruangrungsi N. Pharmacognostic Specification and Mangiferin Content of Aquilaria crassna Leaves. Pharmacogn J. 2018;10(2):293-8.

12. Rabinarayan A, Switu J, Rudrappa C, Vinay S. Pharmacognostical and Phytochemical Analysis on Leaves of Homalium ceylanicum (Gardn.) Benth. Pharmacogn J. 2018;10(2):272-7.

13. Sorabh KA, Venkatachalam K, Parthiban P, Ramraj N. Pharmacognostic and phyto-physio chemical investigation of the Leaves of Siam weed- Chromolaena odorata (L) King and Robinson. Drug Invention Today. 2014;6(2):96-101.

14. Folorunso AE, Awosode OD. Comparative anatomy of invasive and non-invasive species in the family Asteraceae in Nigeria. Int J Biol Chem Sci. 2013;7(5):1804-19.

15. Adedeji O, Jewoola OA. Importance of Leaf Epidermal Characters in the Asteraceae Family. Not Bot Horti Agrobot Cluj Napoca. 2008;36(2):7-16.

16. Wagner GJ, Wang E, Shepherd RW. New approaches for studying and exploiting an old protuberance, the plant trichome. Ann Bot. 2004;93(1):3-11.

17. Svoboda KP, Svoboda TG, Syred A. A Closer Look: Secretory Structures of Aromatic and Medicinal Plants. Herbal Gram. 2001;53:34-43.

18. Debashisha P, Santosh KD, Gouri KD. Preliminary phytochemical screening and Pharmacogcostic studies of the common weeds, Mimosa pudica Linn. Chromolaena odorata Linn. And Tragia involucrata Linn. Collected from Ganjam District, Odisha: A Comparative Study. Research Journal of Pharmacognosy and Phytochemistry. 2012;4(2):92-6.

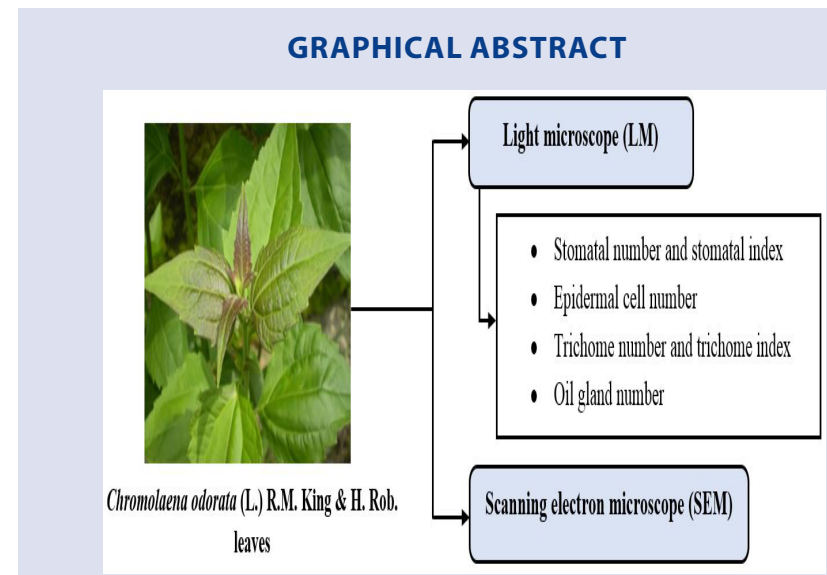

\section{SUMMARY}

- Chromolaena odorata (L.) R.M. King and H. Rob. is a species in family Asteraceae. It has been widely used as medicinal plants for a long time. In Thailand, $C$. odorata is locally used to treat skin diseases and insect bites.

- This study provided leaf constant values of microscopic characters of leaf in term of stomatal number, stomatal index, epidermal cell number, trichome number, trichome index and oil gland number of $C$. odorata in Thailand. Light microscope (LM) attached a digital camera and scanning electron microscope (SEM) were used in this study.

- The anomocytic stomata and multicellular non-glandular trichomes were found on both upper and lower epidermis of $C$. odorata, while oil glands were found on only lower epidermis of the leaf. The microscopic leaf constant numbers of C. odorata were established and could be used for the species identification of $C$. odorata in Thailand.

\section{ABOUT AUTHORS}

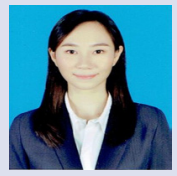

Yamon Pitakpawasutthi: She has completed her Ph.D. in Public Health Sciences from College of Public Health Sciences, Chulalongkorn University. She graduated her Bachelor degree of Thai Traditional Medicine from Prince of Songkla University. She focused on her researches regarding scientific evidence based - traditional Thai and Alternative Medicines. Her career involves herbal drug standardization, chemical qualitative/quantitative analyses and biological activity evaluation.

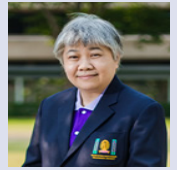

Chanida Palanuvej: She is an Associate Professor at College of Public Health Sciences, Chulalongkorn University. She focused her researches on scientific evidence based - Traditional Thai and Alternative Medicines. Her career involves herbal drug standardization, chemical qualitative/quantitative analyses and biological activity evaluation. She has collaborated with Department of Thai Traditional and Alternative Medicine, Ministry of Public Health for establishing "Pharmacognostic Specification of Thai Crude Drugs" which have been printed as reference books in 2007 (Volume 1) and 2013 (Volume 2). 
Nijsiri Ruangrungsi: He is an Associate Professor at College of Public Health Sciences, Chulalongkorn University. He pursued the career of Pharmacognosy curriculum as well as research on chemistry of natural products. During 40 years of researches, he has got enormous experiences in plant taxonomy, phytochemistry and herbal medicine. At present, he still shares his body of knowledge and expertise in various opportunities. He is an expert in medicinal plants and pharmacognosy of Ministry of Public Health. He is appointed to be a committee in the National Science and Technology Development Board of National Science and Technology Development Agency (NSTDA).

Cite this article: Pitakpawasutthi Y, Palanuvej C, Ruangrungsi N. Microscopic Leaf Constant Numbers of Chromolaena odorata in Thailand. Pharmacog J. 2018;10(6)Suppl:s95-s99. 